\title{
Assessment of distribution and sources of pyrogenic carbon in the lower course of the Guadiana River (SW Iberian Peninsula)
}

José M. De la Rosa 1,2,*

Email: jmrosa@irnase.csic.es

José M. Martins 3

António Monge Soares 2

M. Fátima Araújo 2

${ }^{1}$ Instituto de Recursos Naturales y Agrobiología de Sevilla, Consejo Superior de Investigaciones Científicas (IRNAS-CSIC), Avenida Reina Mercedes 10, 41012 Sevilla, Spain

2 Centro de Ciências e Tecnologias Nucleares, Instituto Superior Técnico, Universidade de Lisboa, Estrada Nacional 10 (km 139,7), Bobadela LRS, 2695-066 Lisbon, Portugal

3 CIMA, Faculdade de Ciências e Tecnologia, Campus de Gambelas, Universidade do Algarve, 8005139 Faro, Portugal

AQ1

\begin{abstract}
Purpose

The main goal of this work was to determine the pyrogenic carbon $(\mathrm{PyC})$ distribution in surficial sediments for the last $40 \mathrm{~km}$ of the Guadiana River (SW Iberian Peninsula). In addition, the changes in the contribution of terrestrial and marine organic matter (OM) sources and their relationship with the PyC contents were assessed.
\end{abstract}

\section{Materials and methods}

Sediments were collected from 22 stations within the lower course of the Guadiana River. All the samples were analyzed for total organic carbon (TOC), total nitrogen $(\mathrm{TN})$, organic carbon to nitrogen atomic ratios $(\mathrm{C} / \mathrm{N})$, and stable carbon isotope ratio $\left(\delta^{13} \mathrm{C}\right)$ as indicators of changes in the sources of $\mathrm{OM}$. PyC was determined according to the chemo-thermal oxidation method (CTO-375).

\section{Results and discussion}

TOC ranged from 0.25 to $2.37 \% \mathrm{dw}$. The greatest TOC contents were located in sediments collected at the middle estuary. The $\mathrm{C} / \mathrm{N}$ values ranged from 7.7 to 12.7 , with slight relative increase in the marine input compared to pre-Alqueva times. Similar $\mathrm{C} / \mathrm{N}$ ranges are representative of native soil OM, lacustrine OM, and local sedimentary $\mathrm{OM}$. The $\delta{ }^{13} \mathrm{C}$ values of the sediment samples ranged from -25.0 to $-27.6 \%$ illustrating a signature of $\mathrm{C}_{3}$ higher plants, marsh-plants, lacustrine plants, and freshwater algae present in the area of study and in the forests located upstream. PyC ranged between 0.17 and $0.74 \mathrm{gkg}^{-1}$, with the highest contents measured in samples located close to urbanized areas. Sediments collected at the middle estuary, within a rural area, showed the lowest proportions of PyC relative to the percent of TOC $(\leq 4 \%$ TOC). The negative relationship between $\mathrm{PyC}$ to TOC ratio and TOC contents confirmed the selective preservation of PyC to degradation in the sedimentary $\mathrm{OM}$ of the Guadiana estuary. The carbon isotope composition of the final material after applying the CTO-375 method (hereafter called $\delta^{13} \mathrm{C}_{\mathrm{PyC}}$ ) was $<-30 \%$, suggesting that the PyC fraction was mainly composed of a mixture of fossil fuels and $\mathrm{C}_{3}$-charred biomass. Nevertheless, selective loss of the less recalcitrant $\mathrm{OM}$ fractions due to degradation and/or chemical alteration might contribute to lighter carbon isotope values of PyC. 


\section{Conclusions}

Geochemical data showed that sedimentary OM was composed of a mix of different OM sources, with a slight increase in the marine input after the Alqueva dam went into operation. The PyC content was higher close to urbanized areas of the Guadiana River estuary. The selective preservation of PyC in the sedimentary OM of the Guadiana estuary was observed.

\section{Keywords}

Black carbon

CTO-375 method

Estuaries

Recent sediments

Refractory organic matter

Soot

Responsible Editor: Frank G. A. Verheijen

\section{Introduction}

Pyrogenic carbon (PyC), also called black carbon, is a relatively inert form of condensed carbon products originated from incomplete combustion processes of biomass or fossil fuels, which are heated to relatively high temperatures $\left(<700^{\circ} \mathrm{C}\right)$ under low or no oxygen. It comprises a variety of materials, from lightly charred biomass to soot (Lehmann 2007). The PyC can be found in soils, sediments, ice, atmospheric aerosols, rainwater, and river and ocean water (Masiello and Druffel 1998; Dittmar et al. 2008). The traditional view of PyC, being an inert C pool, was based on radiocarbon measurements supporting its persistence in some soils and sediments for millennia (Thevenon et al. 2010; de Lafontaine and Asselin 2011). However, recent experiments suggested rather rapid degradation of some PyC forms (De la Rosa and Knicker 2011; Zimmermann et al. 2012), with mean residence times considerably lower than those estimated by other authors (Hockaday et al. 2006; Norwood et al. 2013). In fact, this is consistent with the heterogeneity of PyC formed under different conditions. For instance, every wildfire provides unique combinations of fuels and temperatures, which in turn will produce a range of different forms of PyC. Low-temperature PyC will undergo biologically driven mineralization faster than high-temperature PyC (Baldock and Smernik 2002). Yet, the pyrogenic process confers larger chemical and microbial recalcitrance to these materials, and consequently, longer mean residence times in the environment in comparison to the original biomass from which they are produced. Therefore, $\mathrm{PyC}$ can be considered a genuine $\mathrm{C}$ sink and a significant component of the global C cycle (Kuhlbusch 1998; Gustafsson et al. 2001). There are contrasting estimations of the PyC discharged annually into the ocean, ranging from $1 \mathrm{Tg} \mathrm{yr}^{-1}$ up to 16-275 years ${ }^{-1}$ (Dickens et al. 2004; Flores-Cervantes et al. 2009). Nevertheless, Suman et al (1997) estimated that about $10 \mathrm{Tg}$ of PyC are discharged annually into coastal areas via both aeolian and fluvial contributions. Similarly, Ducret (1994) calculated that the deposition of atmospheric PyC into oceans is approximately $7 \pm 3 \mathrm{Tg} \mathrm{C} \mathrm{yr}^{-1}$. Jaffé et al. (2013) estimated the global riverine flux of dissolved $\mathrm{PyC}$ from soils to oceans is $26.5 \pm 1.8 \mathrm{Tg} \mathrm{C} \mathrm{yr}^{-1}$. This value is in the same order of magnitude as previous estimations of annual PyC production from vegetation fires (Kuhlbusch and Crutzen 1995 ). Fossil fuel combustion-derived particles, charcoal produced by biomass burning, or petrogenic $\mathrm{C}$ forms are transported through aeolian, surface runoff, and fluvial transport, being coastal sediments and marine waters the ultimate receiver of these forms of PyC (Lim and Cachier 1996). All estimation models indicated that riverine fluxes and surface runoff are significant PyC contributors to sediments at the continental shelf and coastal areas, whereas only half of the total atmospheric deposition of PyC to the ocean surface occurs over the continental margins. Moreover, almost all PyC deposition ( $\geq 90 \%)$ to ocean sediments occurs in nearshore sediments rather than in open ocean sediments (Suman et al. 1997). In summary, less than $10 \%$ of the area under the world oceans receives the major contribution of sedimentary PyC. Thus, even small changes in the relative abundance of PyC in these environments may be significant at a global scale. In addition, it is well known that storage conditions in coastal and estuarine environments, particularly in anoxic sediments, are ideal for PyC preservation (De la Rosa et al. 2008). Consequently, alterations of environmental conditions and fluxes could affect PyC preservation and dynamics. 
This study focuses on the assessment of PyC stored in recent sediments from the lower course and estuary of the Guadiana River (SW Iberian Peninsula). This region is of environmental importance because it comprises several protected areas included in Spanish and Portuguese National-Preserve Networks and the European Natura 2000 Network, such as the Natural reserve "Sapal de Castro Marim e Vila real de Sto Antonio" and The Natural Area "Marismas de Isla Canela e Isla Cristina."

The increase of anthropogenic activities carried out during the last decades at the Guadiana estuary, including urbanization, port, and recreational development, have caused significant environmental impacts (Erzini 2005 ). Also noticeable is the construction of several dams in the middle and lower course of the Guadiana River. For instance, the Alqueva dam, the biggest dam in Europe with a storage capacity of ca. $4150 \mathrm{hm}^{3}$, became operational in 2001. Several recent studies have reported changes in the sediment load discharges and estuarine dynamics after this dam went into operation (Caetano et al. 2006; Chícharo et al. 2006; Oliveira et al. 2006; Delgado et al. 2010; González et al. 2007).

The southwestern (SW) area of the Iberian Peninsula has a Mediterranean climate with very high forest fire incidence due to the combination of high temperatures and dry periods (González-Pérez et al. 2004). During the twentieth century, fire was used as a management practice by grassland farmers of SW of the Iberian Peninsula. An estimation of PyC production in the form of particulate residues or aerosols (soot) emitted by forest fires was conducted for Andalusia. It was estimated that up to 31,222 $\mathrm{Mg}$ of PyC can be produced by forest fires every year, at a rate of $1.8 \mathrm{Mg}$ burnt ha ${ }^{-1}$. Part of this PyC, between 767 and $920 \mathrm{Mg}$ year $^{-1}$, can be emitted in the form of aerosols (soot) to the atmosphere and after some time ( $40 \mathrm{~h}$ to 1 month) deposited and incorporated into sediments worldwide. Part of this considerable amount of charred material is transported by wind or by the Guadiana River to the estuary.

A couple of recent studies assessed the abundance of black carbon (PyC-like material) in a few sediments taken from the Guadiana estuary and the adjacent continental shelf before Alqueva dam became operational (De la Rosa et al. 2011; Sánchez-García et al. 2013). In this study, the state of the OC and PyC pools were analyzed for the first time, as well as the sedimentary OM sources in Guadiana riverine sediments collected after the dam became operational.

Despite the important roles and significance played by $\mathrm{PyC}$, ambiguity persists when complex matrices, such as aquatic sediments, are considered. One of the major constraints to establish confident PyC estimations at a regional and global scale is the lack of a standardized method capable of detecting all types of PyC. Consequently, there is a diversity of analytical techniques currently in use (Kuhlbusch 1998; Middelburg et al. 1999; Druffel 2004; Hammes et al. 2007; De la Rosa et al. 2011). Most studies performed thermal and chemical oxidations of OM, being the $\mathrm{C}$ residue after oxidation determined as the PyC. However, other highly aromatic materials from sedimentary metamorphism (petrogenic) are accounted by using these PyC assessment methods. Thus, coal, graphitized carbon, and pure graphite are included in the oxidized material (Veilleux et al. 2009). In this study, the chemo-thermal oxidation method (CTO-375; Gustafsson et al. 2001) was applied. This method is able to isolate the most recalcitrant fraction of PyC (i.e., soot, graphitic black carbon) from complex sedimentary matrices containing abundant carbonates. Therefore, it has been widely applied to quantify PyC in sediment matrices.

The sedimentary OM was characterized by means of elemental analysis: TOC, TN, C/N, and stable carbon isotope analysis $\left(\delta^{13} \mathrm{C}\right)$. Such parameters have been widely used to determine changes in OM sources in lacustrine sediments, tidal marsh sediments, coastal areas, or continental shelves (e.g., Meyers 1994 ; Hedges and Oades 1997; Lamb et al. 2006; Perdue and Koprivnjak 2007; Burdloff et al. 2008). The $\delta^{13} \mathrm{C}$ of the PyC-enriched material was also measured. The degree to which the $\delta^{13} \mathrm{C}$ value of pyrogenic material recovered from sediments and soils can currently be interpreted as an environmental indicator is hampered by a poor understanding of the processes leading to physical fractionation of $\mathrm{C}_{3}$ - and $\mathrm{C}_{4}$-derived pyrogenic $\mathrm{OM}$ during both production (Das et al. 2010 ) and transport to a site of deposition. This study brings further data in this field, which are strictly needed for a development of its potential as a natural tracer for the study of pyrogenic OM degradation and its interaction with the environment (Bird and Ascough 2012).

\section{Study area}

The Guadiana River basin has an area of ca. $67,000 \mathrm{~km}^{2}$ and a length of $810 \mathrm{~km}$. It is the fourth largest river in the 
Fig. 1

Map of the lower course of the Guadiana River and location of the 22 sampling stations

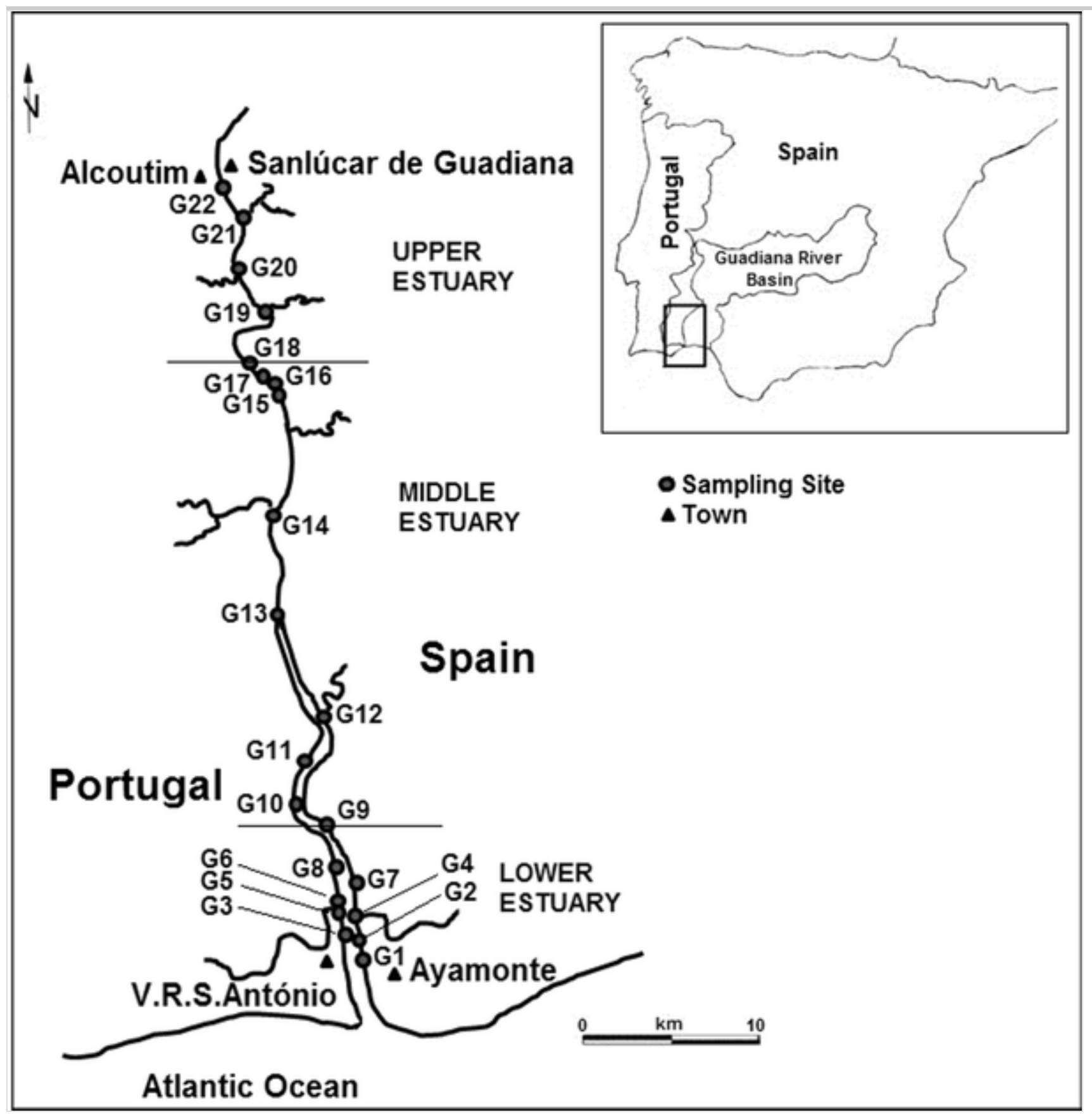

Before reaching the estuarine zone, the Guadiana River crosses approximately $130 \mathrm{~km}$ of rural area without point sources of anthropogenic pollutants (Ferreira et al. 2003). The flow of the Guadiana estuary is highly variable, at a seasonal and inter-annual scale (González et al. 2007). This pattern produces severe droughts and episodic floods in the river basin. For example, the monthly river discharge ranged from $<10$ to $4660 \mathrm{~m}^{3} \mathrm{~s}^{-1}$ for the period $1947-$ 2001 , with an average flow of $156 \mathrm{~m}^{3}$, decreasing to $83 \mathrm{~m}^{3} \mathrm{~s}^{-1}$ during the last decades. The flow of the Guadiana River has been extensively modified during the decades due to a range of anthropogenic activities, including damming, mining, urbanization, deforestation, and dredging (Delgado et al. 2010). Besides this, due to the Mediterranean climate of the area, characterized by hot and dry summers followed by cool and relatively wet winters, which alternate with frequent annual droughts, forest fires are a recurrent phenomenon. An average of 205

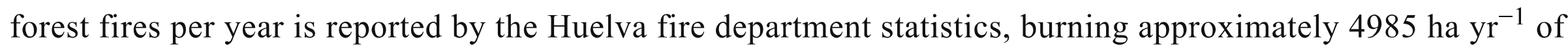
forest area (Zamora et al. 2010). In addition, grassland farmers of the SW Iberian Peninsula commonly used the fire-after-crop practice to facilitate tillage and to sterilize the soil (as disease control) during the twentieth century. Thus, biomass-derived PyC, dominantly composed of char and charcoal particles more prone to sedimentation and transport by means of rivers or water runoff, is likely to occur in the study area. Additional sources of PyC are port traffic in the Ayamonte (Spain) and Vila Real de Sto. Antonio (Portugal) harbors, vehicular traffic over the Guadiana international bridge as well as other anthropogenic activities in the towns located upstream.

The Guadiana estuary is divided into three sub-areas: upper (fluvial), middle, and lower (marine) estuary (Fig. 1). The fluvial area comprises mainly the freshwater section, still with a tidal influence but with a salinity close to zero (fluvial freshwater $\left.<0.5 \mathrm{~g} \mathrm{~kg}^{-1}\right)$. The middle section is the salinity-mixing zone $\left(0.5-25 \mathrm{~g} \mathrm{~kg}^{-1}\right)$, whereas in the lower estuary, salinity is usually very close to seawater $\left(>25 \mathrm{~g} \mathrm{~kg}^{-1}\right)$ (Chícharo et al. 2006).

The upper estuary consists mainly of gravel and sand from the drainage basin. The middle estuary is dominated by poorly sorted sediment, with grain size ranging from gravels to clay and silt. The fraction of mud decreases downstream and well-sorted medium sand (quartz, feldspar, bioclasts, plus lithic components of diverse origin) lies 
at the lower estuary. In addition, some gravel, either mixed with sand or in small isolated pockets, are observed in few (and generally deep) locations of the lower estuary (Dias et al. 2004). These (lower, middle, upper) sectors are concordant with distinct ecohydrological characteristics that were described by Chícharo et al. (2001).

The estuary is influenced by semi-diurnal mesotidal tides and is usually partially stratified in its lower and middle sections, depending on river flow and tidal stage, being well mixed in the upper section. The estuary is located in a region highly vulnerable to climate change, due to a predicted decrease in rainfall (IPCC 2001), and increasingly subjected to urban development.

AQ5

For this study, a total of 22 surficial $(0-15 \mathrm{~cm})$ sediment samples were collected using a Smith-McIntyre grab, in June 2008, along the lower course of the Guadiana River, covering a section of ca. $40 \mathrm{~km}$ between the river mouth and the Alcoutim town (Fig. 1). Sampling sites were selected along the riverbed of the main stream channel and at the shores of the Spanish and Portuguese margins. For each sampling site, a combination of three subsamples were taken, immediately stored in sealed plastic bags, and kept at $-20^{\circ} \mathrm{C}$. Finally, samples were freeze dried and homogenized prior to analysis.

\section{Analytical work}

\subsection{Elemental analysis}

Freeze-dried samples were used for geochemical analysis. Total C (TC) and TN contents were determined in triplicate on ground and homogenized aliquots (10-20 mg) using an elemental analyzer (Carlo-Erba EA-1110 microanalyzer). Total OC content determination was performed on decarbonated samples. Finely ground and homogenized sediment $(1 \mathrm{~g})$ was treated with $10 \mathrm{ml}$ of $2 \mathrm{M} \mathrm{HCl}(3 \times)$ in $50 \mathrm{ml}$ Teflon centrifuge tubes (NALGENE Labware), washed (30 $\mathrm{ml}$ distilled water) and centrifuged (4000 rpm, $10 \mathrm{~min})$. This step was repeated ( $3 \times)$ before the samples were freeze dried and reweighed. The instrumental readings were checked against aliquots of $2 \mathrm{mg}$ of sulfanilamide standard $\left(\mathrm{C}_{6} \mathrm{H}_{8} \mathrm{~N}_{2} \mathrm{O}_{2} \mathrm{~S}\right.$ from Sigma-Aldrich Co, USA). The analytical error based on triplicate analyses was within 4 to $6 \%$ for both TOC and TN.

\subsection{Stable carbon isotope analysis $\left(\delta^{13} \mathrm{C}\right)$}

Carbon isotope analysis $\left(\delta^{13} \mathrm{C}\right)$ was carried out on decarbonated sediments and PyC-enriched sediments with an elemental analyzer interfaced to a continuous flow isotope ratio mass spectrometer (Sercon 20-20 EA-IRMS; Sercon Ltd). Aliquots (5-10 mg) of each sample were packed into $\mathrm{Sn}$ capsules and combusted in excess $\mathrm{O}_{2}$ at $1000{ }^{\circ} \mathrm{C}$ in a reactor packed with chromium oxide, copper oxide, and silver wool. Values are expressed in the $\delta$ notation as per mil deviation (\%) from corresponding international standards and referred to Pee Dee Belemnite $\left({ }^{13} \mathrm{C} /{ }^{12} \mathrm{C}, \mathrm{PDB}\right)$. External working standard materials were inserted every five samples to monitor the working conditions of the analyzer. The analytical precision $( \pm 1 \sigma)$ was in the range $\pm 0.1-0.2 \%$. Data reproducibility was checked by replicate analysis of samples.

\subsection{Pyrogenic $\mathrm{C}$ determination; chemo-thermal oxidation method (CTO-375)}

We applied the method developed by Gustafsson et al. (2001). Briefly, small aliquots (ca. $40 \mathrm{mg}$, to prevent charring) of dry and finely ground decarbonated sediment were weighted $(p \pm 0.01 \mathrm{mg})$ and heated $\left(375 \pm 1{ }^{\circ} \mathrm{C}\right.$; $24 \mathrm{~h}$ ) in duplicate to remove non-PyC material. A constant air flux of $250 \mathrm{~mL} \mathrm{~min}^{-1}$ was maintained through the furnace. After the thermal treatment, the residual C (i.e., the PyC content) was determined as above for elemental analysis. The analytical error was within 3 to $7 \%$ for all the samples analyzed.

\section{Results and discussion}

\subsection{Elemental and isotopic analysis of sediments}

Table 1 shows the TOC, TN, C/N, and $\delta{ }^{13} \mathrm{C}$ values of the bulk sediments and of the remaining material after the CTO-375 treatment. The TOC content of sediments ranged from 0.25 (G22) to 2.37 (G9) wt\% (mean $1.25 \pm$ $0.50 \mathrm{wt} \%$ ) and $\mathrm{TN}$ ranged from 0.03 to $0.28 \mathrm{wt} \%$ (mean $0.16 \pm 0.06 \mathrm{wt} \%$ ), which are typical values for estuarine sediments (Nieuwenhuize et al. 1994). The TOC concentration highly correlated with TN concentration $(r=0.959$, $p<0.001$ ), indicating that $\mathrm{N}$ is predominantly fixed in the OM (Sabel et al. 2005). In general, TOC and TN 
contents were greater in samples from the middle estuary (G9 to G18). Lower values of TOC ( 0.50 to $1.40 \mathrm{wt} \%$; mean $0.88 \mathrm{wt} \%)$ and TN ( 0.07 to $0.16 \mathrm{wt} \%$; mean $0.10 \mathrm{wt} \%)$ were reported recently by Sánchez-García et al. $(2009,2013))$ for sediments taken in the continental-marine transition area of the Gulf of Cádiz before the Alqueva dam was operational. However, we cannot establish a direct comparison to the data presented here because those samples belong to an area located from 5 to $48 \mathrm{~km}$ of distance to the Guadiana River mouth. Concerning the atomic TOC/TN ratio $(\mathrm{C} / \mathrm{N}$ index), the presence or absence of cellulose in the plant sources of $\mathrm{OM}$ to estuaries and lakes influences the $\mathrm{C} / \mathrm{N}$ ratios of sediments. Thus, they can be used as an indicator of the predominant OM sources in aquatic ecosystems (e.g., Thornton and McManus 1994; Meyers 1997).

Phytoplankton $\mathrm{C} / \mathrm{N}$ ratio varies from 6 to 9 in natural systems (Hollugan et al. 1984). Bacterioplankton is N-rich, with C/N 2.6-4.3 (Lee and Fuhrman 1987). In contrast, terrestrial vegetation normally has relatively high C/N ratios of $>12$ (Prahl et al. 1980) as it is composed predominantly of lignin and cellulose, which are nitrogen poor. $\mathrm{C}_{3}$ vascular plant material has $\mathrm{C} / \mathrm{N}$ ratios of around 12 and over (Tyson 1995), while $\mathrm{C}_{4}$ grasses typically have $\mathrm{C} / \mathrm{N}$ ratios of above 30 (Meyers, 1994). $\mathrm{C} / \mathrm{N}$ values for the sedimentary OM (Table 1) ranged from 7.7 (G13) to 12.7 (G17), being $\leq 10$ in most cases (avg. of $9.5 \pm 1.3$ ). Similar $\mathrm{C} / \mathrm{N}$ values were reported for salt marsh sediments (Alberts and Filip 1989) and for surface sediments from lacustrine samples (Meyers and Ishiwatari. 1993). In general, $\mathrm{C} / \mathrm{N}$ values obtained are slightly lower than those reported for surficial sediments from the marine estuary taken in 2001 before the Alqueva dam was operational (avg, 10.9 1.1; De la Rosa et al. 2008) and similar to those obtained from the Iberian continental shelf, which ranged from 7.0 to 9.8 by Sánchez-García et al. (2009; 2013). Coastal sediments receive OM from autochthonous sources (derived from in situ sources, such as plants and algae growing on the sediment surface) and allochthonous sources (organic material transported to the sediment from elsewhere, such as with the tide or a river). The slight reduction on the $\mathrm{C} / \mathrm{N}$ values compared to preAlqueva data may indicate a dilution of terrestrial and freshwater sources of OM by a relative increase in marine (tidal) sedimentary OM, which could be due to a smaller reach of freshwater phytoplankton and terrigenous OM. Nevertheless, early diagenesis can modify elemental composition and hence may be also responsible for a relative diminution of $\mathrm{C} / \mathrm{N}$ values (Meyers and Ishiwatari 1993), due to microbial immobilization of nitrogenous material accompanied by the remineralization of carbon. Nevertheless, this would indicate an alteration on the conditions of the ecosystem.

\section{Table 1}

Location details, analytical data, and pyrogenic carbon (PyC) concentrations of sediment samples

\begin{tabular}{|c|c|c|c|c|c|c|c|c|c|c|c|}
\hline Sample & $\begin{array}{l}\text { Latitude } \\
\qquad \mathbf{N}\end{array}$ & $\begin{array}{c}\text { Longitude } \\
\text { W }\end{array}$ & $\begin{array}{l}\text { Depth } \\
\text { (m) }\end{array}$ & Location detail & $\begin{array}{c}\text { TOC } \\
(\%)\end{array}$ & $\begin{array}{l}\text { TN } \\
(\%)\end{array}$ & $\begin{array}{l}\delta^{13} \mathrm{C} \\
\text { Sed } \\
(\%)\end{array}$ & $\begin{array}{c}\mathrm{OC} / \mathrm{N} \\
\text { atomic } \\
\text { ratio }\end{array}$ & $\begin{array}{c}\text { PyC } \\
\left(\text { g kg }^{-1}\right. \\
\text { sed. })\end{array}$ & $\begin{array}{c}\text { PyC } \\
(\% \\
\text { TOC) }\end{array}$ & $\begin{array}{c}\delta^{13} C_{P y C} \\
(\%)\end{array}$ \\
\hline $\mathrm{G} 22$ & $\begin{array}{l}37^{\circ} 27^{\prime} \\
51.42^{\prime \prime}\end{array}$ & $\begin{array}{l}7^{\circ} 27^{\prime} \\
58.20^{\prime \prime}\end{array}$ & 3.1 & $\begin{array}{l}\text { Close to } \\
\text { Alcoutim town }\end{array}$ & 0.25 & 0.03 & -25.9 & 9.7 & 0.29 & 11.7 & -31.4 \\
\hline G21 & $\begin{array}{l}37^{\circ} 27^{\prime} \\
15.48^{\prime \prime}\end{array}$ & $\begin{array}{l}7^{\circ} 27^{\prime} \\
23.76^{\prime \prime}\end{array}$ & 2.8 & $\begin{array}{l}\text { "Barranco de los } \\
\text { mosquetes" } \\
\text { stream input }\end{array}$ & 0.88 & 0.11 & -27.6 & 9.3 & 0.55 & 6.2 & -32.1 \\
\hline G20 & $\begin{array}{l}37^{\circ} 26^{\prime} \\
11.88^{\prime \prime}\end{array}$ & $\begin{array}{l}7^{\circ} 27^{\prime} \\
29.70^{\prime \prime}\end{array}$ & 2.0 & $\begin{array}{l}\text { "Torneiro" } \\
\text { stream input }\end{array}$ & 0.38 & 0.04 & -26.9 & 11.1 & 0.45 & 11.8 & -30.4 \\
\hline G19 & $\begin{array}{l}37^{\circ} 25^{\prime} \\
12.78^{\prime \prime}\end{array}$ & $\begin{array}{l}7^{\circ} 26^{\prime} \\
49.86^{\prime \prime}\end{array}$ & 3.9 & $\begin{array}{l}\text { "El Romerano" } \\
\text { meander }\end{array}$ & 1.81 & 0.24 & -27.1 & 8.8 & 0.71 & 3.9 & -30.3 \\
\hline G18 & $\begin{array}{l}37^{\circ} 24^{\prime} \\
16.56^{\prime \prime}\end{array}$ & $\begin{array}{l}7^{\circ} 27^{\prime} \\
15.18^{\prime \prime}\end{array}$ & 3.6 & & 2.01 & 0.24 & -26.7 & 9.8 & 0.62 & 3.1 & -30.4 \\
\hline G17 & $\begin{array}{l}37^{\circ} 23^{\prime} \\
53.52^{\prime \prime}\end{array}$ & $\begin{array}{l}7^{\circ} 26^{\prime} \\
50.52^{\prime \prime}\end{array}$ & 2.3 & Alamo town & 1.31 & 0.12 & -27.3 & 12.7 & 0.74 & 5.6 & -32.5 \\
\hline G16 & $\begin{array}{l}37^{\circ} 23^{\prime} \\
45.06^{\prime \prime}\end{array}$ & $\begin{array}{l}7^{\circ} 26^{\prime} \\
40.74^{\prime \prime}\end{array}$ & 1.6 & & 1.68 & 0.23 & -27.2 & 8.5 & 0.54 & 3.2 & -32.0 \\
\hline G15 & $\begin{array}{l}37^{\circ} 23^{\prime} \\
39.42^{\prime \prime}\end{array}$ & $\begin{array}{l}7^{\circ} 26^{\prime} \\
37.02^{\prime \prime}\end{array}$ & 2.3 & & 1.71 & 0.22 & -27.4 & 9.1 & 0.55 & 3.2 & -30.2 \\
\hline G14 & $\begin{array}{l}37^{\circ} 20^{\prime} \\
57.60^{\prime \prime}\end{array}$ & $\begin{array}{l}7^{\circ} 26^{\prime} \\
42.90^{\prime \prime}\end{array}$ & 3.6 & $\begin{array}{l}\text { "Odeleite" } \\
\text { stream input }\end{array}$ & 1.65 & 0.22 & -27.2 & 8.8 & 0.69 & 4.2 & -30.4 \\
\hline G13 & $\begin{array}{l}37^{\circ} 18^{\prime} \\
55.98^{\prime \prime}\end{array}$ & $\begin{array}{l}7^{\circ} 26^{\prime} \\
36.30^{\prime \prime}\end{array}$ & 1.2 & & 1.25 & 0.19 & -27.2 & 7.7 & 0.54 & 4.3 & -30.3 \\
\hline G12 & $\begin{array}{l}37^{\circ} 16^{\prime} \\
47.40^{\prime \prime}\end{array}$ & $\begin{array}{l}7^{\circ} 25^{\prime} \\
22.98^{\prime \prime}\end{array}$ & 1.8 & & 1.47 & 0.19 & -27.1 & 9.0 & 0.27 & 1.8 & -30.1 \\
\hline
\end{tabular}




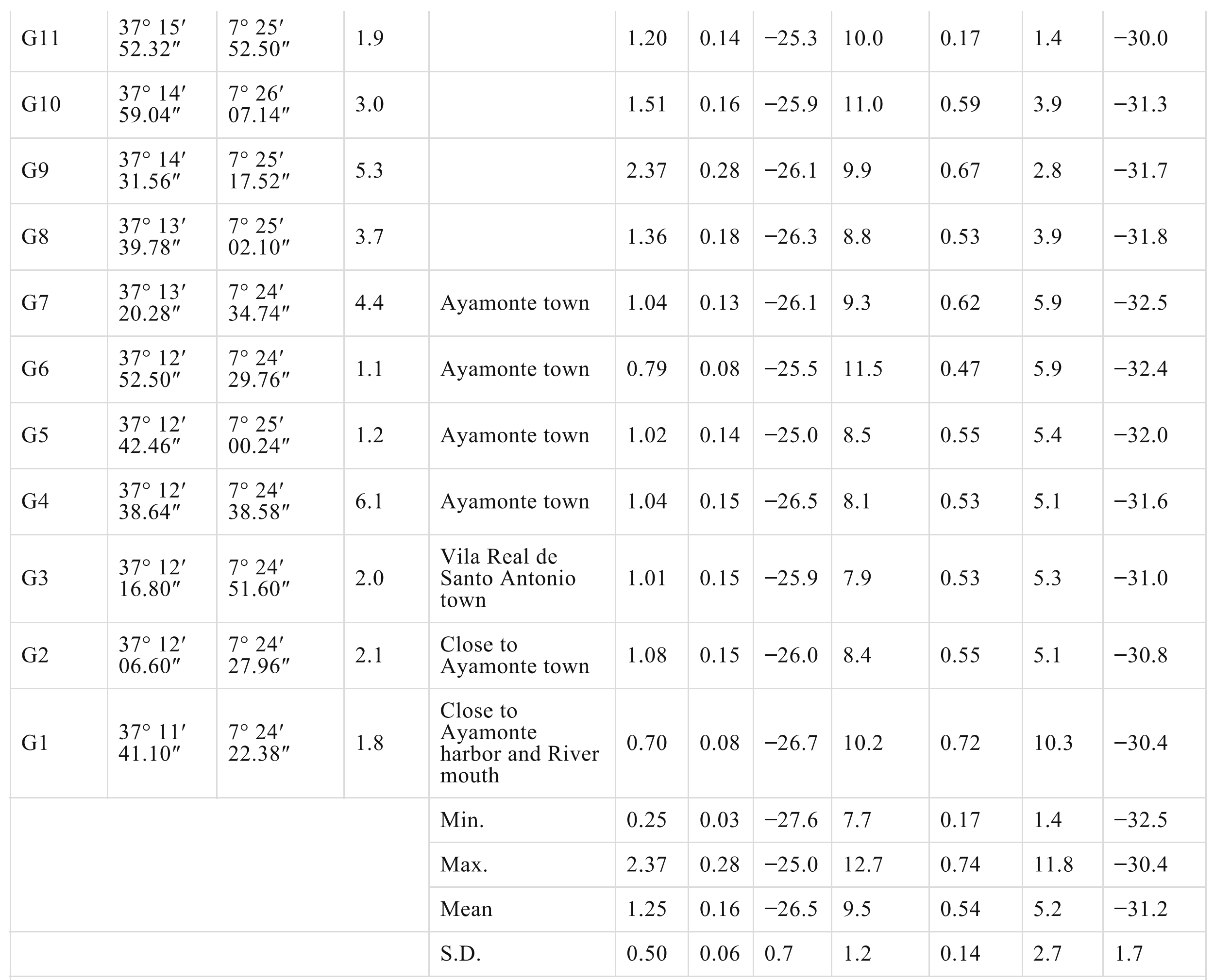

Values obtained for decarbonated sediments by the CTO-375 method

$T O C$ total organic carbon, $T N$ total nitrogen

The $\delta^{13} \mathrm{C}$ values ranged from $-25.0 \%$ (G5) to $-27.6 \%$ (G21) (avg, $-26.5 \%$; Table 1 ), most of the samples located in the middle estuary being depleted in $\delta^{13} \mathrm{C}(\leq-27 \%)$. Stable isotopes $\left(\delta^{13} \mathrm{C}\right)$ are usual indicators for reconstructing OM sources and transformation of sedimentary OM (Meyers, 1994). The $\delta^{13} \mathrm{C}$ for $\mathrm{C}_{3}$ biomass ranges from -23 to $-34 \%$, with an average of ca. $-27 \%$ (Meyers 1997). Lacustrine-derived OM is normally isotopically indistinguishable from OM from land plants (Meyers and Ishiwatari 1993), while typical marine end member values are -20 to $-18 \%$ (Holtvoeth et al. 2005). Bulk $\delta^{13} \mathrm{C}$ and $\mathrm{C} / \mathrm{N}$ should in theory reflect the relative amounts of the OM sources. The values in Table 1 illustrate mixed contributions of $\mathrm{C}_{3}$ marsh-plants (Cistus grandiflurus, Cistus sp., and Halimium halimiforum are abundant in the area; Ruiz de la Torre 1990), lacustrine plants (Meyers and Ishiwatari 1993), $\mathrm{C}_{3}$ freshwater algae ( -26 to $-30 \%$; Meyers, 1994), and $\mathrm{C}_{3}$ vascular plants (Castanea sativa, Pinus pinea, Pinus pinaster, or Quercus suber are abundant in the forests located upstream; González-Pérez et al. 2008). Nevertheless, the reliability of $\delta^{13} \mathrm{C}$ values as recorders of the source of OM is uncertain when decomposition affects the sediments (Thornton and McManus 1994). Some studies have suggested that microorganisms may also have an impact on the $\delta^{13} \mathrm{C}$ and $\mathrm{C} / \mathrm{N}$ of recent sediments (e.g., Malamud-Roam and Ingram 2001). For instance, the $\delta^{13} \mathrm{C}$ values of living Spartina alterniflora, a $\mathrm{C}_{4}$ marsh grass present in the area of study (typically $\delta^{13} \mathrm{C}=-11$ to $-13 \%$ ), changed in surface sediments from salt marshes of the eastern USA due to the presence of bacteria from -18 up to $-24 \%$ (Peterson et al. 1980). Benner et al. (1987) demonstrated that laboratory decomposition of $S$. alterniflora produced a progressive shift in the $\delta^{13} \mathrm{C}$ of sedimentary $\mathrm{OM}$ from -13 to $-17 \%$. Thus, the marine signature could be masked by microbial diagenesis of the sedimentary OM. AQ7

Figure 2 plots $\mathrm{C} / \mathrm{N}$ vs. $\delta^{13} \mathrm{C}$ data. Usually, a significant negative correlation would occur between $\delta^{13} \mathrm{C}$ and $\mathrm{C} / \mathrm{N}$ because sedimentary $\mathrm{OM}$ with high $\mathrm{C} / \mathrm{N}$ ratio has much lighter $\delta^{13} \mathrm{C}$ values ( $\mathrm{Wu}$ et al. 1999). In addition, numerous studies across the world showed a gradient of $\delta^{13} \mathrm{C}$ and $\mathrm{C} / \mathrm{N}$ in estuaries along their river axis, which 
characterized the shift downstream from fluvial to marine OM inputs (e.g., Thornton and McManus 1994; Middelburg et al. 1999; Lamb et al. 2006). In our case, there is no correlation between $\delta^{13} \mathrm{C}$ and $\mathrm{C} / \mathrm{N}\left(r^{2}=0.049\right)$. This fact could be due to efficient sediment mixing and/or the presence of numerous OM sources with differing $\delta^{13} \mathrm{C}$ values (Graham et al. 2001).

Fig. 2

Plot of the stable carbon isotopic composition $\left(\delta^{13} \mathrm{C} \%\right.$ ) versus the total organic carbon to total nitrogen atomic ratio $(\mathrm{C} / \mathrm{N})$. Values of source materials (boxes) are based on Meyers (1994)

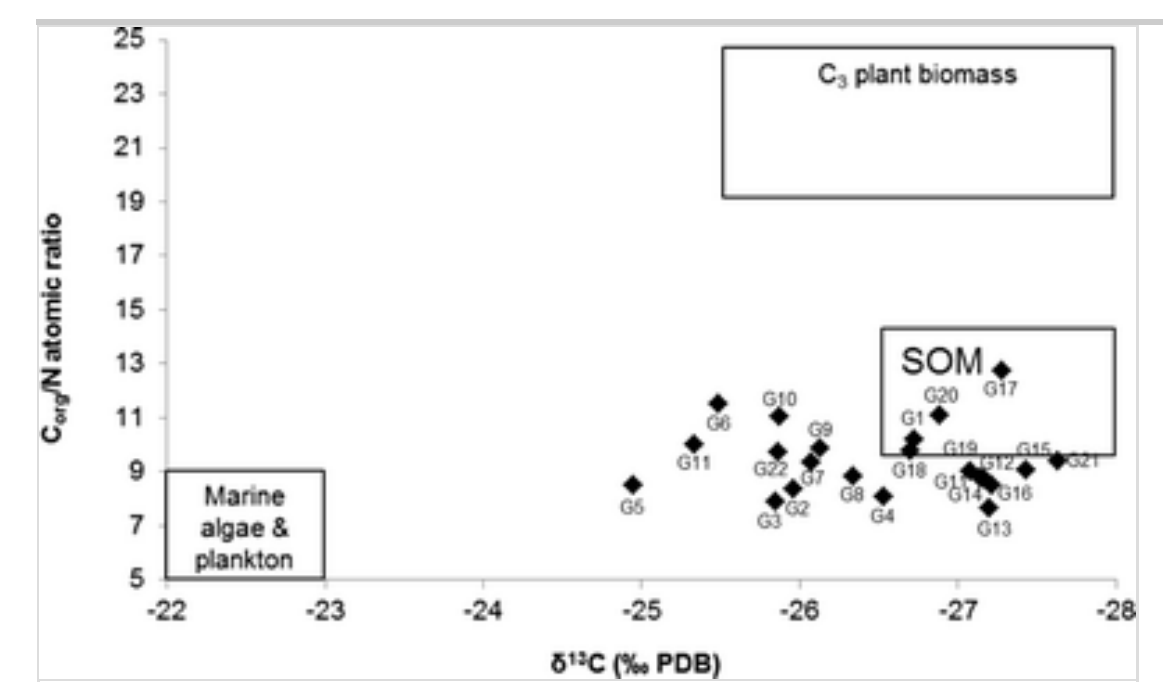

AQ8

\subsection{Pyrogenic $\mathrm{C}$ distribution and sources}

PyC was detected in all sediment samples with concentrations ranging from 0.17 (G11) to 0.74 (G17) $\mathrm{g} \mathrm{kg}^{-1} \mathrm{dry}$ weight (average $0.54 \pm 0.14 \mathrm{~g} \mathrm{~kg}^{-1} \mathrm{dw}$ ). These values are of the same order of magnitude than those previously published for graphitic black carbon in sediments from the Gulf of Cádiz. They consisted of 0.47 to $1.63 \mathrm{~g} \mathrm{~kg}^{-1} \mathrm{dw}$ at the Atlantic Iberian margin (Middelburg et al. 1999), 0.30 to $1.10 \mathrm{~g} \mathrm{~kg}^{-1} \mathrm{dw}$ and 0.10 to $1.10 \mathrm{~g} \mathrm{~kg}^{-1} \mathrm{dw}$ (avg. $0.40 \mathrm{~g} \mathrm{~kg}^{-1} \mathrm{dw}$ ) by De la Rosa et al. (2011) and Sánchez-García et al. (2013), respectively, for sediments taken in 2001 at the continental margin of the Gulf of Cádiz.

Samples G11 and G12 located in the central estuary, presented the lowest concentrations $\left(0.17\right.$ and $0.27 \mathrm{~g} \mathrm{~kg}^{-1} \mathrm{dw}$, respectively), in contrast with the samples taken close to residential areas that exhibited the highest PyC contents (G17 at Alamo town, $0.74 \mathrm{~g} \mathrm{~kg}^{-1} \mathrm{dw}$; G1 at Ayamonte harbor, $0.71 \mathrm{~g} \mathrm{~kg}^{-1} \mathrm{dw}$ ). Nevertheless, no significant trend was found related with the river axis. This result seems to confirm the efficient sediment mixing as well as the importance of anthropogenic sites as sources of PyC.

Concerning the method of PyC assessment, Gélinas et al. (2001) noted that previous measurements of PyC in sediments by the CTO-375 method might have been biased because of charring of the sedimentary OM. This problem was illustrated by increasing PyC concentrations with increasing OC. Figure 3 displays the determined PyC fraction versus TOC content. In this study, no significant correlation between PyC and TOC is evidenced $\left(r^{2}\right.$ $=0.1424, p<0.001$ ), which confirms that measurements were not affected by in situ charring. The relative contribution of $\mathrm{PyC}$ to TOC (in wt\%) ratio has been used in discussing pollution phenomena (Gustafsson and Gschwend 1998). Results obtained for the studied samples ranged from $1.4 \mathrm{wt} \%$ (G11) to $11.8 \mathrm{wt} . \%$ (G20), which are comparable to the PyC/TOC ratios reported by Sánchez-García et al. (2013) by using the same method for sediments from the Gulf of Cadiz (2-15 wt \%). In our case, sediments from the middle estuary, within a rural area, presented the lowest values of PyC/TOC ( $\leq 4 \%)$. In contrast, enhanced ratios $(\geq 10 \%)$ were found in samples located close to Ayamonte harbor, Ayamonte town, Vila Real de Sto. Antonio town and Alcoutim town (G1, G20, G22; Table 1 and Fig. 1). The relationship between PyC and the distance from the Guadiana mouth found by Sánchez-García et al. (2009) for continental margin sediments of the Gulf of Cadiz was not observed. Taking into account the characteristics of the PyC assessed by the CTO-375 analysis within the combustion continuum model, the location of the samples enriched in $\mathrm{PyC}$ (close to sites with clear anthropogenic activities) may be interpreted by the contribution of soot-derived condensates.

Fig. 3

Relation between total organic carbon (TOC; wt \%) and pyrogenic carbon content ( $\mathrm{PyC} w \mathrm{t} \%)$ 


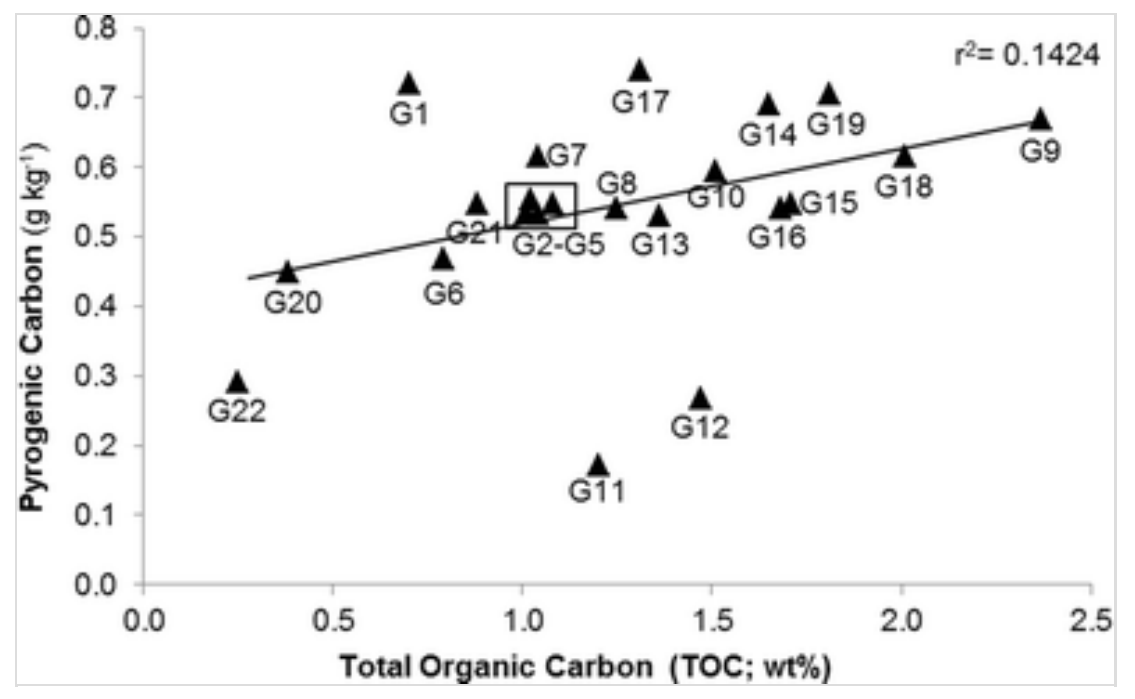

The correlation between the PyC to TOC and the TOC values $(r=-0.8027 ; p<0.001)$ are depicted in Fig. 4 . A trend for TOC poor samples $(\leq 1 \%$ TOC) to contain a larger relative abundance of PyC is shown (see G1-G7; G20-G22). In general, the contribution of PyC to TOC is the result of two independent processes: the fluxes of $\mathrm{PyC}$ and $\mathrm{OC}$ to the sediments and the remineralization processes removing organic $\mathrm{C}$ from the sediments (Burdige 2005 ). In our case, this trend is not explained by lower sedimentation rates, as usually occurs in deep-sea sediments, but by the selective preservation of $\mathrm{PyC}$, less sensitive to postdepositional degradation than bulk sedimentary OM. This means that biogeochemical processes may remove PyC less effectively than $\mathrm{OC}$ in this estuarine environment.

\section{Fig 4}

Relation between total organic carbon $(T O C$; wt $\%)$ and the contribution of pyrogenic carbon to organic carbon $(\mathrm{PyC} / \mathrm{TOC} \%)$

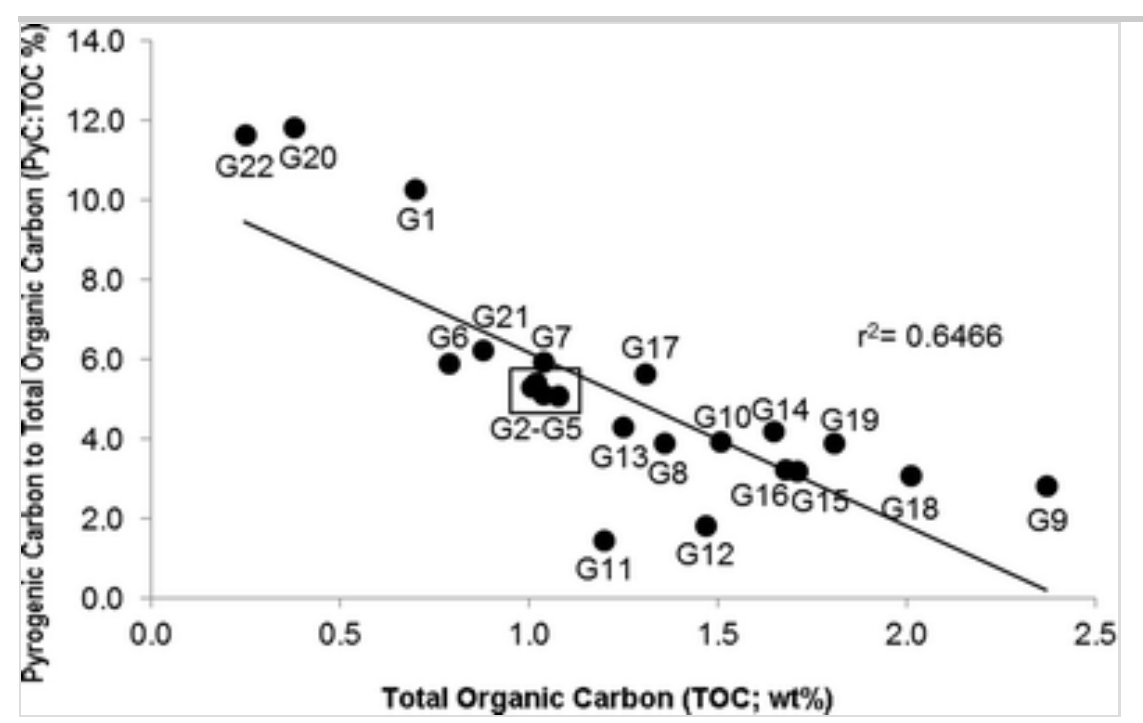

The isolated PyC-enriched fractions were analyzed for $\delta^{13} \mathrm{C}$ ratios $\left(\delta^{13} \mathrm{C}_{\mathrm{PyC}}\right)$. They ranged from -32.5 to $-30.4 \%$ (avg. $\delta^{13} \mathrm{C}_{\mathrm{PyC}}-31.2 \%$ ). PyC in sediments is usually derived from the burning of fossil fuels, vegetation biomass, or weathering of rocks. The typical $\delta^{13} \mathrm{C}$ values of PyC from petrogenic nature range from -19.4 to $-21.3 \%$ (Dickens et al. 2004); thus, the isotopic data suggest that the PyC present is a mixture of soot derived from fossil fuels and $\mathrm{C}_{3}$-charred biomass (Friedli et al. 1986; Bird and Ascough 2012). In addition, depletion in the $\delta{ }^{13} \mathrm{C}$ values of PyC-enriched material after the CTO-375 method $(<-30 \%)$ could be interpreted as indicative of a greater contribution of fossil fuels to the $\mathrm{PyC}$ instead of vegetation biomass burning. Other aspects such as the isotopic fractionation during the formation of soot PyC (charring) from starting biomass or the different fractionation processes occurring postdeposition for $\mathrm{OC}$ and soot $\mathrm{PyC}$ may alter the $\mathrm{C}$ isotope composition. Bird and Ascough (2012) reviewed the effects of charring on the stable isotope fractionation $\left(\Lambda \delta^{13} \mathrm{C}_{\mathrm{PyC}}\right)$ during pyrolysis of $\mathrm{C}_{3}$ and $\mathrm{C}_{4}$ plant material. In the majority of instances, $\Lambda \delta^{13} \mathrm{C}_{\mathrm{PyC}}$ consisted of a depletion of $1-2 \%$, but changes up to $-11.0 \%$ were identified in some studies (Czimczik et al. 2002; Krull et al. 2003; Das et al. 2010). During charring, oxidative "weathering" has been reported (Ascough et al. 2011), which may be responsible for a loss of isotopically distinct indigenous carbon, with the addition of oxygen to the pyrogenic aromatic skeleton, and an increase in carboxylic groups.

Concerning microbial diagenesis, $\mathrm{OM}$ is a mixture of different types of compounds with different isotopic content. Amino acids from marine plankton, for instance, are enriched in ${ }^{13} \mathrm{C}$ by $-17 \%$ on average. Bacteria and algae, which are usually enriched in ${ }^{13} \mathrm{C}$ compared with $\mathrm{C}_{3}$ vascular plants, contain a high level of labile compounds and decompose chemically and biologically more rapidly than vascular plants (Valiela et al. 1985). The CTO-375 oxidation process of the sedimentary OM removes preferentially labile OM, which becomes less significant to bulk 
organic $\delta^{13} \mathrm{C}$, producing a shift in the $\delta^{13} \mathrm{C}_{\mathrm{PyC}}$ to lighter carbon isotope values. Taking into account the depletion in the $\delta^{13} \mathrm{C}_{\mathrm{PyC}}$ (mean value $-31.2 \%$ ) and the negative correlation between the PyC and the TOC contents $(r=-$ 0.8027; $p<0.001$ ), we hypothesize that postdepositional degradation/alteration contributed to losses of isotopically heavy OM.

\section{Conclusions}

Elemental (TOC, TN, C/N) and isotopic $\left(\delta^{13} \mathrm{C}\right)$ data of sediments collected from the last $40 \mathrm{~km}$ of the Guadiana River revealed an efficient mixing of OM from terrestrial, estuarine salt marshes, lacustrine, and freshwater contributions. The $\mathrm{C} / \mathrm{N}$ data suggested a slight increase in the marine contribution, or a smaller reach of freshwater phytoplankton and terrigenous OM compared to samples taken in the same area before the Alqueva dam became operational.

PyC accounted from 0.17 to $0.74 \mathrm{~g} \mathrm{~kg}^{-1}$, constituting a significant portion of the sedimentary $\mathrm{OM}$ (ca. 2 to $12 \%$ of TOC), especially in the vicinity of urbanized areas of the Guadiana River estuary. The relative enrichment in PyC measured in sediments with low $\mathrm{OC}$ content indicated a selective preservation of $\mathrm{PyC}$ to postdepositional degradation when compared to bulk sedimentary OM. According to the $\delta^{13} \mathrm{C}_{\mathrm{PyC}}$ data, fossil fuels and $\mathrm{C}_{3}$-charred biomass comprised the main sources of $\mathrm{PyC}$, whereas the presence of $\mathrm{PyC}$ weathered from rocks was negligible. Nevertheless, $\delta^{13} \mathrm{C}_{\mathrm{PyC}}$ was affected by postdepositional alteration, which may contribute to a shift of the $\delta^{13} \mathrm{C}$ values to lighter carbon isotope values.

\section{Acknowledgments}

We acknowledge the funding by the Foundation for Science and Technology (FCT) of Portugal for J. Martins' $\mathrm{PhD}$. Grant (SFRH/BD/45528/2008). PhDJ.M. de la Rosa is the recipient of a fellowship from the JAE-Doc subprogram financed by the CSIC and the European Social Fund (ESF). The Spanish Ministry of Economy and Competitiveness (MINECO GCL2012-37041) is thanked for the financial support of this study. A. Miller is thanked for the revision of the manuscript.

\section{References}

Alberts JJ, Filip Z (1989) Sources and characteristics of fulvic and humic acids from a salt marsh estuary. Sci Total Environ 81-82:353-361

Ascough PL, Bird MI, Francis SM, Thornton B, Midwood AJ, Scott AC, Apperley D (2011) Variability in oxidative degradation of charcoal: influence of production conditions and environmental exposure. Geochim Cosmochim Acta 75:2361-2378

Baldock JA, Smernik RJ (2002) Chemical composition and bioavailability of thermally altered Pinus resinosa (Red pine) wood. Org Geochem 33:093-1109

Benner R, Fogel ML, Sprague EK, Hodson RE (1987) Depletion of ${ }^{13} \mathrm{C}$ in lignin and its implications for stable carbon isotope studies. Nature 329:708-710

Bird MI, Ascough PL (2012) Isotopes in pyrogenic carbon: a review. Org Geochem 42:1529-1539

Bird MI, Cali JA (1998) A million-year reeord of fire in sub-Saharan Afriea. Nature 394:767-769 AQ9

Burdige DJ (2005) Burial of terrestrial organic matter in marine sediments: a re-assessment. Glob Biogeochem Cycles 19, GB4011. doi: 10.1029/2004GB002368

Burdloff D, Araújo MF, Jouanneau JM, Mendes I, Monge Soares AM, Dias JMA (2008) Sources of organic carbon in the Portuguese continental shelf sediments during the Holocene period. App Geochem 23:2857-2870

Caetano M, Vale C, Falcão M (2006) Particulate metal distribution in Guadiana estuary punctuated by flood episodes. Estuar Coast Shelf Sci 70:109-116 
Chícharo MA, Chícharo L, Galvão H, Barbosa A, Marques MH, Andrade JP, Esteves E, Miguel C, Gouveia C (2001) Status of the Guadiana estuary (south Portugal) during 1996-1998: an ecohydrological approach. Aquat Eco Health Manag 4:1-17

Chícharo MA, Chícharo L, Morais P (2006) Inter-annual differences of ichthyofauna structure of the Guadiana estuary and adjacent coastal area (SE Portugal/SW Spain): before and after Alqueva dam construction. Estuar Coast Shelf Sci 70:39-51

Corredeira C, Araújo MF, Jotranneau J-M (2008) Copper, zine and lead impaet in SW Hberian shelf sediments: an assessment of reeent historieal ehanges in Guadiana river basin. Geoehem J-42:319-329

Czimczik CI, Preston CM, Schmidt MW, Werner R, Schulze D-E (2002) Effects of charring on mass, organic carbon, and stable carbon isotope composition of wood. Org Geochem 33:1207-1233

Das O, Wang Y, Hsieh Y (2010) Chemical and carbon isotopic characteristics of ash and smoke derived from burning of $\mathrm{C}_{3}$ and $\mathrm{C}_{4}$ grasses. Org Geochem 41:263-269

De la Rosa JM, Knicker H (2011) Bioavailability of N released from N-rich pyrogenic organic matter: an incubation study. Soil Biol Biochem 43:2368-2373

De la Rosa JM, González-Pérez JA, Hatcher PG, Knicker H, González-Vila FJ (2008) Determination of refractory organic matter in marine sediments by chemical oxidation, analytical pyrolysis and solid-state ${ }^{13} \mathrm{C}$ nuclear magnetic resonance spectroscopy. Eur J Soil Sci 59:430-438

De la Rosa JM, Sánchez García L, de Andrés JR, González-Vila FJ, González-Pérez JA, Knicker H (2011) Contribution of black carbon in recent sediments of the gulf of Cadiz. Applicability of different quantification methodologies. Quat Int 243:264-272

De Lafontaine G, Asselin H (2011) Soil charcoal stability over the Holocene across boreal northeastern North America. Quat Res 76:196-200

Delgado J, Nieto JM, Boski T (2010) Analysis of the spatial variation of heavy metals in the Guadiana Estuary sediments (SW Iberian Peninsula) based on GIS-mapping techniques. Estuar Coast Shelf Sci 88:71-83

Dias JMA, Gonzalez R, Ferreira Ó (2004) Natural versus anthropic causes in variations of sand export from river basins: an example from the Guadiana river mouth (Southwestern Iberia). Rapid transgression into semienclosed basins. Pol Geol Ins Spe Pap, Gdansk pp 95-102

Dickens AF, Gélinas Y, Hedges JI (2004) Physical separation of combustion and rock sources of graphitic black carbon in sediments. Mar Chem 92:215-223

Dittmar T (2008) The molecular level determination of black carbon in marine dissolved organic matter. Org Geochem 39:396-407

Ducret J (1994) Incorporation du carbone particulaire aux retombées humides: Implications geochimiques. PhD thesis Universite Paris 7, Paris

Druffel ERM (2004) Comments on the importance of black carbon in the global carbon cycle. Mar Chem 92:197-200

Erzini K (2005) Trends in NE Atlantic landings (southern Portugal): identifying the relative importance of fisheries and environmental variables. Fish Ocean 14:195-209

Ferreira AM, Martins M, Vale C (2003) Influence of diffuse sources on levels and distribution of polychlorinated biphenyls in the Guadiana River estuary, Portugal. Mar Chem 83:175-184

Flores-Cervantes DX, Reddy CM, Gschwend PM (2009) Inferring black carbon concentrations in particulate 
Friedli H, Lötscher H, Oeschger H, Siegenthalet U, Stauffer B (1986) Ice core record of the 13C/12C ration of afmospheric CO2 in the past two centuries. Nature 324:237-238

Gélinas Y, Prentice KM, Baldock JA, Hedges JI (2001) An improved thermal oxidation method for the quantification of soot/graphitic black carbon in sediments and soils. Environ Sci Tech 35:3519-3525

González R, Araújo MF, Burdloff D, Cachão M, Cháscalo J, Corredeira C, Dias JMA, Fradique C, Ferreira J, Gomes C, Machado A, Mendes I, Rocha F (2007) Sediment and pollutant transport in the Northern Gulf of Cádiz: a multi-proxy approach. J Mar Syst 68:1-23

González-Pérez JA, González-Vila FJ, Almendros G, Knicker H (2004) The effect of fire on soil organic matter -a review. Env Int 30:855-870

González-Pérez JA, González-Vila FJ, González-Vázquez R, Arias ME, Rodríguez J, Knicker H (2008) Use of multiple biogeochemical parameters to monitor the recovery of soils after forest fires. Org Geochem 39:940944

Graham MC, Eaves MA, Farmer JG, Dobson J, Fallick AE (2001) A study of carbon and nitrogen stable isotope and elemental ratios as potential indicators of source and fate of organic matter in sediments of the Forth Estuary, Scotland. Estuar Coast Shelf Sci 52:375-380

Gustafsson Ö, Gschwend PM (1998) The flux of black carbon to surface sediments on the New England continental shelf. Geochim et Cosmochim Acta 62:465-472

Gustafsson Ö, Bucheli TD, Kukulska Z, Andersson M, Largeau C, Rouzaud JN, Reddy CM, Eglinton TI (2001) Evaluation of a protocol for the quantification of black carbon in sediments. Glob Biogeochem Cycles 15:881890

Hammes K, Schmidt MWI, Smernik RJ, Currie LAR, Ball WP, Nguyen TH, Louchouarn P, Houel S, Gustafsson O, Elmquist M, Cornelissen G, Skjemstad JO, Masiello CA, Song J, Peng P, Mitra S, Dunn JC, Hatcher PG, Hockaday WC, Smith DM, Hartkopf-Froder C, Bohmer A, Luer B, Huebert BJ, Amelung W, Brodowski S, Huang L, Zhang W, Gschwend PM, Flores-Cervantes DX, Largeau C, Rouzaud J-N, Rumpel C, Guggenberger G, Kaiser K, Rodionov A, Gonzalez-Vila FJ, Gonzalez-Perez JA, de la Rosa JM, Manning DAC, Lopez-Capel E, Ding L (2007) Comparison of black carbon quantification methods to measure fire-derived (black/elemental) carbon in soils and sediments using reference materials from soil, water, sediment and the atmosphere. Glob Biogeochem Cycles 21:1-18

Hedges JI, Oades JM (1997) Comparative organic geochemistry of soils and marine sediments. Org Geochem 27:319-361

Hockaday W, Grannas AM, Kim S, Hatcher PG (2006) Direct molecular evidence for the degradation and mobility of black carbon in soils from ultrahigh-resolution mass spectral analysis of dissolved organic matter from a fire-impacted forest soil. Org Geochem 37:501-510

Hollugan SG, Montoya JP, Nevins JL, McCarthy JJ (1984) Vertical distribution and partitioning of organic carbon in mixed, frontal and stratified waters of the English Channel. Mar Ecol Prog Series 14:111-127

Holtvoeth K, van Griensven A, Seuntjens P, Vanrolleghem PA (2005) Sensitivity analysis for hydrology and pesticide supply towards the river in SWAT. Phys Chem Earth 30:518-526

Houel S, Louehouarn P, Lueotte M, Canuel R, Ghaleb B (2006) Transloeation of soil organie matter following reservoir impoundment in boreal systems: implieations for in situ produetivity. Limnol Oeeanogr 51:1497-1513

Krull ES, Skjemstad JO, Graetz D, Grice K, Dunning W, Cook G, Parr JF (2003) C-13-depleted charcoal from $\mathrm{C}_{4}$ grasses and the role of occluded carbon in phytoliths. Org Geochem 34:1337-1352 
Kuhlbusch TAJ, Crutzen PJ (1995) Toward a global estimate of black carbon in residues of vegetation fires representing a sink of atmospheric $\mathrm{CO}_{2}$ and a source of O2. Glob Biogeochem Cycles 9:491-501

Lamb A, Wilson GP, Len MJ (2006) A review of coastal palaeoclimate and relative sea-level reconstructions using $\delta^{13} \mathrm{C}$ and $\mathrm{C} / \mathrm{N}$ ratios in organic material. Earth Sci Rev 75:29-57

Lee S, Fuhrman JA (1987) Relationhips between biovolume and biomass of naturally derived marine bacterioplankton. Appl Env Microbiol 53:1298-1303

Lehmann J (2007) A handful of carbon. Nature 447:143-144

tehmann MF, Bernaseoni SM, Barbieri A, MeKenzie JA (2002) Preservation of organie matter and alteration of its earbon and nitrogen isotope composition during simulated and in situ early sedimentary diagenesis. Geoehim Cosmoehim Aeta 66:3573-3584

Lim B, Cachier H (1996) Determination of black carbon by chemical oxidation and thermal treatment in recent marine and lake sediments and Cretaceous-Tertiary clays. Chem Geol 131:143-154

Malamud-Roam F, Ingram BL (2001) Carbon isotopic compositions of plants and sediments of tide marshes in the San Francisco Estuary. J Coast Res 17:17-29

Masiello CA (2004) New direetions in black earbon organie geoehemistry. Mar Chem 92:201-213

Masiello CA, Druffel ERM (1998) Black carbon in deep-sea sediments. Science 280:1911-1913

Matson EA, Brinson MM (1990) Stable earbon isotopes and the $\mathrm{C} / \mathrm{N}$ ratio in Pamlieo and Netuse Estuaries,

North Carolina. Limnol Oeeanogr 35:1290-1300

Meyers PA (1994) Preservation of elemental and isotopic source identification of sedimentary organic matter. Chem Geol 144:289-302

Meyers PA (1997) Organic geochemical proxies of paleoceanographic, paleoclimnologic and paleoclimatic processes. Org Geochem 27:213-250

Meyers PA, Ishiwatari R (1993) Lacustrine organic geochemistry — an overview of indicators of organic matter sources and diagenesis in lake sediments. Org Geochem 20:867-900

Middelburg JJ, Nieuwenhuize J, Van Breugel P (1999) Black carbon in marine sediments. Mar Chem 65:245252

Muri G, Cermelj B, Faganeli J, Braneelj A (2002) Blaek earbon in Slovenian alpine laeustrine sediments. Ehemosph-46:1225-1234

Nieuwenhuize J, Maas YEM, Middelburg JJ (1994) Rapid analysis of organic carbon and nitrogen in particulate materials. Mar Chem 44:217-224

Norwood MJ, Louchouarn P, Kuo L-J, Harvey OR (2013) Characterization and biodegradation of water-soluble biomarkers and organic carbon extracted from low temperature chars. Org Geochem 56:111-119

Oliveira A, Fortunato A, Pinto L (2006) Modelling the hydrodynamics and the fate of passive and active organisms in the Guadiana estuary. Estuar Coast Shelf Sci 70:76-84

Penner JE, Eddleman H, Novakov T (1993) Towards the development of a global inventory for black earbon emissions. Atm Env 27:1277-1295 
Perdue EM, Koprivnjak JF (2007) Using the $\mathrm{C} / \mathrm{N}$ ratio to estimate terrigenous inputs of organic matter to aquatic environments. Estuar Coast Shelf Sci 74:65-72

Peterson BJ, Howarth RW, Lipschutz F, Ashendorf D (1980) Salt marsh detritus: an alternative interpretation of stable carbon isotope ratios and fate of Spartina alterniflora. Oikos 34:173-177

Polvillo O, González-Pérez J, Boski T, González-Vila FJ (2009) Struetural features of humie aeids from a sedimentary sequenee in the Guadiana estuary (Portugal-Spain border). Org Geoehem 40:20-28

Prahl FG, Bennett JT, Carpenter J (1980) The early diagenesis of aliphatic hydrocarbons and organic matter in sedimentary particulates from Dabob Bay, Washington. Geochim Cosmochim Acta 44:1967-1976

Ribeiro L, Renato S, Carreira P, Wagener A (2008) Black earbon contents and distribution in sediments from the Southeastern Brazilian Coast (Guanabara Bay). J Braz Chem Soe 19:1277-1283

Ruíz de la Torre J (1990) Mapa forestal de España. In: ICONA (eds) Memoria General. Escala 1:200.000, Madrid

Sabel M, Bechtel A, Püttmann W, Hoernes S (2005) Palaeoenvironment of the Eocene Eckfeld Maar Lake (Germany): implications from geochemical analysis of the oil shale sequence. Org Geochem 36:873-891

Sánchez-García L, de Andrés JR, Martín-Rubí JA, Louchouarn P (2009) Diagenetic state and source characterization of marine sediments from the inner continental shelf of the Gulf of Cádiz (SW Spain), constrained by terrigenous biomarkers. Org Geochem 40:184-194

Sánchez-García L, de Andrés JR, Gélinas Y, Schmidt MW, Louchouarn P (2013) Different pools of black carbon in sediments from the Gulf of Cádiz (SW Spain): method comparison and spatial distribution. Mar Chem 151:13-22

Suman DO, Kuhlbusch TAJ, Lim B (1997) Marine sediments: a reservoir for black carbon and their use as spatial and temporal records of combustion. In: Clark JS, Cachier H, Goldammer JG, Stocks B (eds) Sediment records of biomass burning and global change. NATO ASI Series I: global environmental change, vol 51. Springer, Berlin, pp 271-293

Thevenon F, Williamson D, Bard E, Anselmetti F, Beaufort L, Cachier H (2010) Combining charcoal and elemental black carbon analysis in sedimentary archives: implications for past fi re regimes, the pyrogenic carbon cycle, and the human-climate interactions. Glob Planet Sci 72:381-389

Thornton SF, McManus J (1994) Application of organic Carbon and Nitrogen stable isotope and C/N ratios as source indicators of organic matter provenance in estuarine systems: evidence from the Tay Estuary, Scotland. Estuar Coast Shelf Sci 38:219-233

Tyson RV (1995) Sedimentary organic matter: organic facies and palynofacies. Chapman and Hall, London

Valiela I, Teal JM, Allen SD (1985) Decomposition in salt marsh ecosystems: the phases and major factors affecting disappearance of above-ground organic matter. J Exp Mar Biol Ecol 89:29-54

Veilleux MH, Dickens AF, Brandes J, Gélinas Y (2009) Density separation of combustion-derived soot and petrogenic graphitic black carbon: quantification and isotopic characterization. In > IOP Conference Series: Earth and Environmental Science. IOP Publishing, Vol. 5, No. 1, p. 012010

Wu JP, Calvert SE, Wong CS (1999) Carbon and nitrogen isotope ratios in sedimenting particulate organic matter at an upwelling site off Vancouver Island. Estuar Coast Shelf Sci 48:193-203

Zamora R, Molina-Martínez JR, Herrera MA, Rodríguez Silva F (2010) A model for wildfire prevention planning in game resources. Ecol Model 221:19-26 
Zimmermann M, Bird MI, Wurster C, Saiz G, Goodrick I, Barta J, Capek P, Santruckova H, Smernik R (2012) Rapid degradation of pyrogenic carbon. Global Ch Biol 18:3306-3316 